\title{
Nutritional evaluation of Brachiaria brizantha cv. Marandu cultivated in soils developed from basalt and sandstone in the state of Paraná
}

\section{Avaliação nutricional da Brachiaria brizantha cv. Marandu cultivada em solos desenvolvidos de basalto e de arenito no estado do Paraná}

\author{
Geisi Loures Guerra ${ }^{1 *}$; Thierry Becquer ${ }^{2}$; Pedro Rodolfo Siqueira Vendrame ${ }^{3}$;
} Sandra Galbeiro ${ }^{4}$; Osmar Rodrigues Brito ${ }^{5}$; Leandro das Dores Ferreira da Silva ${ }^{4}$; Jaqueline Cazado Felix 6 ; Matheus Rodrigues Lopes ${ }^{7}$; Éderson Luis Henz ${ }^{1}$; Ivone Yurika Mizubuti ${ }^{8}$

\begin{abstract}
Determining the nutritional composition of a pasture is necessary to evaluate its quality, aiming to meet the requirements of feeding animals and guarantee good performance. The quality of the forage biomass produced depends directly on the fertility and type of soil, environmental conditions, and management. In this scenario, the aim was to evaluate the chemical composition, in vitro digestibility of dry matter, and macro- and micronutrient contents of Brachiaria brizantha cv. Marandu cultivated in soils developed from basalt and sandstone in the state of Paraná. A total of 120 forage samples were collected in a soil developed from basalt and 116 in soil developed from sandstone. Forage harvesting occurred in autumn and spring for basalt soil (season effect), and in spring (soil effect) for sandstone soil. Soil samples $(0-20 \mathrm{~cm})$ were collected in the spring season, at the same forage collection sites, to obtain a greater sample representativity regarding climate-soil-plant relationships. Forage samples were separated in leaf blade and stem + sheath, and analyses of dry matter (DM), mineral matter (MM), crude protein (CP), neutral detergent fiber (NDF), acid detergent fiber (ADF), lignin, cellulose, hemicellulose, in vitro dry matter digestibility (IVDMD), total digestible nutrients (TDN), nitrogen, and macro- and micronutrient contents were performed. In soil samples, the contents of $\mathrm{P}, \mathrm{K}, \mathrm{Ca}, \mathrm{Mg}, \mathrm{Mn}$, and $\mathrm{Zn}$ were analyzed. There were season and soil-type effects on the chemical composition of the cultivar studied. The highest levels of protein, NDF, ADF, lignin, and cellulose were obtained in autumn. In samples from soil developed from basalt, higher levels of hemicellulose, IVDMD, and TDN were obtained in the spring. K, P, Mn, and $\mathrm{Zn}$ presented levels within the range recommended for the studied forage, but the values of $\mathrm{Ca}$ and $\mathrm{Mg}$ in autumn and $\mathrm{N}$ in the three studied periods remained below the level considered adequate. Soil nutrient contents were influenced $(P<0.05)$ by the soil source material, and the highest levels of $\mathrm{K}, \mathrm{Ca}, \mathrm{Mg}, \mathrm{Mn}$, and $\mathrm{Zn}$ were observed in soil developed from basalt. Forage cultivated in spring in the soil area developed from basalt, was nutritionally superior in relation to forage cultivated
\end{abstract}

\footnotetext{
${ }^{1}$ Discentes, Curso de Doutorado, Programa de Pós-Graduação em Ciência Animal, Universidade Estadual de Londrina, UEL, Londrina, PR, Brasil. E-mail: geisi_guerra@hotmail.com; ederhenz@gmail.com

2 Eco\&Sols, IRD, INRA, CIRAD, Montpellier SupAgro, Montpellier University, Montpellier, France. E-mail: thierry.becquer@ird.fr

3 Prof. Dr., Departamento de Geociência, UEL, Londrina, PR, Brasil. E-mail: perovendrame@yahoo.com.br

4 Profs. Drs., Departamento de Zootecnia, UEL, Londrina, PR, Brasil. E-mail: sgalbeiro@gmail.com; leandro@uel.br

5 Prof. Dr., Departamento de Agronomia, UEL, Londrina, PR, Brasil. E-mail: osmar@uel.br

6 Discente, Curso de Doutorado, Programa de Pós-Graduação em Agronomia, UEL, Londrina, PR, Brasil. E-mail: jcazfelix@ yahoo.com.br

7 Discente, Curso de Graduação em Medicina Veterinária, UEL, Londrina, PR, Brasil. E-mail: matheusrodrigueslopes1@gmail.com

8 Prof $^{\mathrm{a}} \mathrm{Dr}^{\mathrm{a}}$, Departamento de Zootecnia, UEL, Londrina, PR, Brasil. Bolsista de Produtividade do CNPq. E-mail: mizubuti@uel.br

"Author for correspondence
} 
in the soil developed from sandstone.

Key words: Chemical composition. Leaf blade. Macro and micronutrients. Soil. Stem + sheath.

\section{Resumo}

A determinação da composição nutricional da pastagem é necessária para avaliação da sua qualidade, visando atender as exigências do rebanho e garantir o bom desempenho do plantel. A qualidade da biomassa forrageira produzida depende diretamente da fertilidade e tipo de solo, das condições ambientais e do manejo empregado. Diante deste cenário, objetivou-se avaliar a composição química, digestibilidade in vitro da matéria seca e teores de macro e micronutrientes da Brachiaria brizantha cv. Marandu, cultivada em solos desenvolvidos de basalto e de arenito, no Estado do Paraná. Foram coletadas 120 amostras de forragem em solo desenvolvido de basalto e 116 em solo desenvolvido de arenito. As coletas de forragem ocorreram no outono e na primavera para o solo de basalto (efeito estação do ano), e na primavera (efeito solo) para os solos do arenito. Foram coletadas amostras de solo $(0-20 \mathrm{~cm})$, na estação da primavera, nos mesmos locais da coleta de forragem, visando obter maior representatividade amostral quanto às inter-relações clima-solo-planta. As amostras de forragem foram separadas em lâmina foliar e colmo + bainha, e analisadas quanto aos teores de matéria seca (MS), matéria mineral (MM), proteína bruta (PB), fibra em detergente neutro (FDN), fibra em detergente ácido (FDA), lignina, celulose, hemicelulose, digestibilidade in vitro da matéria seca (DIVMS), nutrientes digestíveis totais (NDT), nitrogênio, macro e micronutrientes. Nas amostras de solo foram avaliados os teores de $\mathrm{P}, \mathrm{K}, \mathrm{Ca}, \mathrm{Mg}, \mathrm{Mn}$ e $\mathrm{Zn}$. Houve efeito da estação e do tipo de solo sobre a composição química da cultivar estudada. Os maiores teores de proteína, FDN, FDA, lignina e celulose foram obtidos no outono. Em amostras provenientes de solo desenvolvido de basalto, foram obtidos maiores teores de hemicelulose, DIVMS e NDT, na primavera. K, P, Mn e Zn apresentaram teores dentro da faixa recomendada para a forrageira estudada, porém os valores de $\mathrm{Ca}$ e $\mathrm{Mg}$ no outono, e $\mathrm{N}$ nos três períodos estudados permaneceram abaixo do nível considerado como adequado. Os teores de nutrientes nos solos foram influenciados $(P<0,05)$ pelo material de origem dos solos, sendo que os maiores teores de $\mathrm{K}, \mathrm{Ca}$, $\mathrm{Mg}, \mathrm{Mn}$ e $\mathrm{Zn}$ foram observados em solo desenvolvido de basalto. A forragem cultivada na primavera, na área de solo desenvolvido de basalto foi nutricionalmente superior em relação à forragem cultivada no solo desenvolvido de arenito.

Palavras-chave: Colmo + bainha. Composição química. Lâmina foliar. Macro e micronutrientes. Solo.

\section{Introduction}

The basis of the productive chain of beef cattle is characterized, essentially, by the production of grazing animals, in view of the high prices of concentrated feed (ALENCAR et al., 2014). The nutritive value of forage is undoubtedly one of the most important factors related to animal production, especially under grazing conditions. Thus, the prior knowledge of its chemical-bromatological composition is of great importance (MAGALHÃES et al., 2015). The quantity and quality of the diet provided are directly related to the consumption and performance of the animals. When grazing conditions allow selection by the animal, its consumption tends to improve, resulting in weight gain (BARBOSA et al., 2007).

The chemical composition of a forage varies within the same species or cultivar, due to the edaphoclimatic conditions, physiological age of the plant, and fertility of the soil. When a pasture faces hot climate conditions, the cell walls of forage epidermal tissue tend to lignify more rapidly, resulting in the reduction of metabolites and nitrogen compounds in the cell contents. In addition, periods of rainfall can paralyze plant growth, and may even lead to the death of its aerial part, resulting in low quality and availability of forage (VAN SOEST, 1994). The maturity of the plant directly influences the productivity and nutritional composition of the leaf blades. As the plant reaches maturity, changes 
are observed in the chemical composition of plant structures and the leaf blade:stem + sheath ratio. In addition, there is a thickening of the wall and decrease in the cellular content, resulting in lower protein content and forage digestibility (GARCIA et al., 2015).

Poor pasture management and low soil fertility lead to serious complications in the productive process, such as decreased physical, chemical and biological properties, leading to reductions in organic matter and forage mass, and an increase in erosion processes (LIMA et al., 2007). These factors alter the root environment and influence the development of plants, and organic matter is important in the supply of nutrients (SILVA; MIELNICZUK, 1998). Several researchers have reported the great influence of fertility and type of soil source material on the formation and maintenance of forage plants (ALENCAR et al., 2014; EUCLIDES et al., 2010; PEDREIRA et al., 2017; PEREIRA et al., 2011; SANTOS et al., 2016; VENDRAME et al., 2010). Fertilization can provide a large increase in the productive capacity of a pasture. An almost immediate response was observed mainly in sandy soils, which have low organic matter content, by providing adequate chemical conditions to the production of the plants and increasing the nutrient content (LIMA et al., 2007; MESQUITA et al., 2004).

Minerals play vital roles in maintaining good animal metabolism (MCDOWELL, 1992), acting on the protection, structural composition of organs and tissues, and as catalysts in enzymatic and hormonal reactions, in addition to maintaining acidbase balance, osmotic pressure of the blood, and water balance of the animal (KHAN et al., 2006). In addition to the need for nutrients of animals, the requirements of plants should also be considered (COSTA et al., 2010).

The mineral composition of forage varies according to factors related to the plant, such as the species, season, age, and morphological structure, as well as fertility, fertilization, and soil type (PEREIRA et al., 2011). An adequate balance of nutrients and their supply to the soil are indispensable for the formation and maintenance of pastures, thus indicating the importance of prior chemical analysis of soils for definition and fertilization recommendations, where necessary (TEIXEIRA, 2016). Plants depend on the availability of soil nutrients for their growth and development, and as a consequence, animals kept under grazing depend on the plants to meet their nutritional needs, which are basically supplied by the forage and indirectly by the soil.

One of the main problems in Brazilian pastures is the continuous removal of nutrients from soils without proper replacement, which contributes to the degradation process (SANTOS et al., 2013; VENDRAME et al., 2010). According to Neely et al. (2009), approximately $73 \%$ of pasture areas present some degree of soil degradation, which is related to compaction due to trampling, excessive grazing, and a gradual reduction in fertility, mainly due to nitrogen, potassium, and calcium deficiency (PACIULLO et al., 2007; VENDRAME et al., 2010). However, despite the fairly common degradation of pastures, the natural fertility levels of tropical soils are quite variable, depending on pedogenetic factors and soil types (SANCHEZ; LOGAN, 1992). For cerrado pastures, Vendrame et al. (2010) showed a great diversity in fertility according to soil texture, with clayey soils being more fertile than sandy soils.

In Paraná, the Paraná Basin region comprises the second and third plateaus and covers most of the state. In the northwest of the state, it is formed by the Caiuá Formation, composed of sandy sediments with fine to medium sandstones, and in the north and central region, it is formed by the Serra Geral Formation, composed of extensive igneous rock spills, predominantly basalt (MINEROPAR, 2001). The sandstone forms soils with high vulnerability to erosion and a texture varying from sandy to medium. They have low organic matter content, chemical fertility, and water retention capacity, 
and high acidity (GAMA et al., 2009; LIMA et al., 2007). In contrast, the soils developed from basalt are characterized by being deep, well drained, and permeable, with a clayey to very clayey texture. They have high iron content, water absorption capacity, organic matter content (FONSECA; CZUY, 2005), and cation exchange capacity (CEC), as well as a high supply of nutrients $(\mathrm{K}, \mathrm{P}, \mathrm{Ca}$, and $\mathrm{Mg}$ [MANTOVANI et al., 2017]), providing characteristics very conducive to crop development.

Chemical analysis to determine the macro- and micronutrient contents of forage serves to evaluate the mineral status of the material provided and the potential for the availability of nutrients, in order to meet the nutritional requirements of the animals. When this does not occur, mineral supplements should be offered to the herd.

Given the high demand for beef, determining the nutritional composition and macro- and micronutrients, both in the plant and in the soil, play a fundamental role in animal production and deserve more detailed studies, generating information and measures in the short term. Based on this issue, the objective of this study was to evaluate the nutritional composition and digestibility of
Brachiaria brizantha $\mathrm{cv}$. Marandu, as well as macro and micronutrients levels in soil and forage, grown in soils developed from basalt and sandstone, which represent the main source materials of the soils in the north and northwest of Paraná.

\section{Material and Methods}

For this study, two cattle farms with Brachiaria brizantha $\mathrm{cv}$. Marandu were selected, with with beef cattle in continuous grazing on soils developed from different sources (basalt and sandstone), located on the third plateau in the north and northwest regions of the state of Paraná. One farm was located in a region with a predominance of basalts and one in a region with a predominance of sandstones. The farm in the basalt region was located in the municipality of Cruzmaltina $\left(24^{\circ} 3^{\prime} 56^{\prime \prime} \mathrm{S}, 51^{\circ} 34^{\prime} 26^{\prime \prime} \mathrm{W}\right)$ with an altitude of $416 \mathrm{~m}$ and area of $18.93 \mathrm{ha}$. The farm in the sandstone region was in the municipality of Uniflor $\left(23^{\circ} 4^{\prime} 54^{\prime \prime} \mathrm{S}, 52^{\circ} 12^{\prime} 49^{\prime \prime} \mathrm{W}\right)$, with an altitude of $490 \mathrm{~m}$ and area 24.2 ha. The soil chemical characteristics of each source material were determined according to the standardized methodologies for the state of Paraná, according to Pavan et al. (1992), and are

shown in Table 1.

Table 1. Mean values of the chemical characteristics of soils developed from basalt and sandstone.

\begin{tabular}{lcccc}
\hline \multirow{2}{*}{ Soil Caracteristics } & \multicolumn{2}{c}{ Basalt } & \multicolumn{2}{c}{ Sandstone } \\
\cline { 2 - 5 } & Mean & SD & Mean & SD \\
\cline { 2 - 5 } O. C. $\left(\mathrm{g} \mathrm{kg}^{-1}\right)$ & 30.6 & 6.5 & 6.8 & 3.9 \\
$\mathrm{pH}\left(\mathrm{CaCl}_{2}\right)$ & 5.6 & 0.2 & 5.0 & 0.6 \\
$\mathrm{SB}\left(\mathrm{cmol}_{\mathrm{c}} \mathrm{kg}^{-1}\right)$ & 10.6 & 2.6 & 3.4 & 1.8 \\
$\mathrm{CEC}\left(\mathrm{cmol}_{\mathrm{c}} \mathrm{kg}^{-1}\right)$ & 15.2 & 2.8 & 7.4 & 2.3 \\
$\mathrm{Al}\left(\mathrm{cmol}_{\mathrm{c}} \mathrm{kg}^{-1}\right)$ & 0.14 & 0.07 & 0.00 & 0.01 \\
$\mathrm{H}+\mathrm{Al}\left(\mathrm{cmol}_{\mathrm{c}} \mathrm{kg}^{-1}\right)$ & 4.5 & 0.5 & 4.0 & 2.0 \\
\hline
\end{tabular}

O. C.: organic carbon; SB: sum of bases; CEC: cation exchange capacity; SD: standard deviation.

A total of 120 forage samples were collected in the soil area developed from basalt and 116 samples in the soil area developed from sandstone. The plants were cut approximately $5 \mathrm{~cm}$ from the soil surface, with the aid of a metal square structure with $0.25 \mathrm{~m}^{2}$ area. Basaltic soil samples were 
collected randomly (zig-zagging) in two different periods, first in autumn (60 samples) and then (60 samples) in spring. In the sandstone, the selection of the sampling points was performed using a georeferenced grid, and the collection occurred in spring.

In the spring season, where the forage was harvested, soil samples were collected from the 0-20 $\mathrm{cm}$ superficial layer. The soil samples were sieved and allowed to dry in a laboratory environment to obtain the air-dried fine earth (ADFE), which was used to determine the phosphorus and potassium contents available in the soil using the Mehlich 1 extractor; the exchangeable calcium and magnesium contents were extracted by $1 \mathrm{M}$ solution of $\mathrm{KCl}$, and micronutrient contents ( $\mathrm{Mn}$ and $\mathrm{Zn}$ ) were extracted by the Mehlich 1, as recommended by Pavan et al. (1992).

The collected forage biomass was conditioned in previously identified plastic bags, weighed immediately to determine the dry matter yield (DMY), and then frozen for morphological separation and analysis. Samples separated in the leaf blades and stem + sheath were weighed and the leaf blade:stem + sheath ratio was calculated. The subsamples were dehydrated in the drying oven with forced air ventilation, maintained at a constant temperature of $60{ }^{\circ} \mathrm{C}$ for $72 \mathrm{~h}$, and ground in a Willey-type mill using a $1 \mathrm{~mm}$ sieve. The samples were analyzed for dry matter (DM), mineral matter (MM), crude protein $(\mathrm{CP})$, and nitrogen $(\mathrm{N})$ contents using the Kjeldahl method, according to AOAC (2000); and neutral detergent fiber (NDF), acid detergent fiber (ADF), and lignin extraction using 72\% sulfuric acid, according to Van Soest et al. (1991). The hemicellulose was calculated by the difference between the NDF and the ADF, and the cellulose by the difference between the ADF and lignin (Detmann et al., 2012). The in vitro dry matter digestibility (IVDMD) was determined according to the method of Tilley and Terry (1963) and the total digestible nutrient content (TDN) was calculated using the equation proposed by Cappelle et al. (2001) for forage, where TDN $=[83.79-$ $(0.4171 \times \mathrm{NDF} \%)]$. The mineral nutrient contents in the plants were determined after nitric-perchloric digestion, using the methodologies recommended by Silva (2009).

Readings were performed after the extraction of the macro- $(\mathrm{K}, \mathrm{P}, \mathrm{Ca}$, and $\mathrm{Mg})$ and micronutrients (Mn and $\mathrm{Zn}$ ) of the plant and soil samples. The $\mathrm{K}$ and $\mathrm{P}$ contents were determined by flame photometry and spectrophotometry, respectively, and those of $\mathrm{Ca}, \mathrm{Mg}, \mathrm{Mn}$, and $\mathrm{Zn}$ by atomic absorption spectrophotometry.

The chemical analyses of forage and soil samples were performed at the Animal Nutrition and Soil Laboratory of the State University of Londrina. The data were submitted to the analysis of variance and $t$-test to compare averages with significance levels of $5 \%$, using the statistical software $\mathrm{R}$, version 3.3.2.

\section{Results and Discussion}

\section{Chemical composition of morphological structures}

The production of dry matter composed of leaf blades and stem + sheath was between 202.2-280.7 $\mathrm{g} \mathrm{m}^{-2}$, and was higher in forage from soil developed from sandstone than in that developed from basalt during the spring. The reverse situation was found for the relationship between the structures (leaf blade and stem + sheath), with a better proportion of leaves during spring and in basalt soil, with values of 1.4 (Table 2). The higher the correlation, the greater the leaf composition in the canopy and the better the pasture quality. The pasture architecture is dependent on the frequency of grazing, management, and environmental conditions, such as soil fertility, nitrogen fertilization, season, and local climate. In addition, it is known that animals show preferences for some parts of the plant, especially the leaf blade (PEDREIRA et al., 2017).

The season and soil origin affected $(P<0.05)$ the chemical variables related to the leaf blade and stem + sheath (Table 2). Higher levels of protein were 
found in the leaf blade DM in the autumn season $(10.4 \%)$, and the reduced content during spring occurred due to the increase in forage maturity, besides the adverse climatic conditions. In relation to the soil source material effect, the highest levels of protein, 88 and $48.9 \mathrm{~g} \mathrm{~kg}^{-1}$, in leaf blade and stem + sheath respectively (Table 2), were observed in forage in the basalt soil. According to Gama et al. (2009), it is common the Brachiaria to present lower levels of protein in less fertile soils, such as

those developed from sandstone.

Table 2. Mean values and standard deviation (SD) of dry matter yield (DMY), leaf blade: stem + sheat ratio (LSR), chemical composition, in vitro dry matter digestibility (IVDMD) and total digestible nutrients (TDN) in dry matter, leaf blades and stem + sheath of Brachiaria brizantha cv. Marandu, cultivated in soils developed from basalt or sandstone, according on the seasons.

\begin{tabular}{|c|c|c|c|c|c|c|}
\hline \multirow{2}{*}{ Item } & \multicolumn{2}{|c|}{ Basalt - Autumn } & \multicolumn{2}{|c|}{ Basalt - Spring } & \multicolumn{2}{|c|}{ Sandstone - Spring } \\
\hline & Mean & $\mathrm{SD}$ & Mean & SD & Mean & SD \\
\hline $\operatorname{DMY}\left(\mathrm{g} \mathrm{m}^{-2}\right)$ & $229.5 \mathrm{~A}$ & 78.8 & $202.2 \mathrm{Bb}$ & 42.9 & $280.7 \mathrm{a}$ & 64.3 \\
\hline \multirow[t]{2}{*}{ LSR } & $1.2 \mathrm{~B}$ & 0.4 & $1.4 \mathrm{Aa}$ & 0.4 & $0.9 \mathrm{~b}$ & 0.2 \\
\hline & \multicolumn{6}{|c|}{ Leaf blade } \\
\hline $\mathrm{DM}\left(\mathrm{g} \mathrm{kg}^{-1}\right)$ & $254.4 \mathrm{~B}$ & 25.5 & $276.6 \mathrm{Ab}$ & 38.0 & $292.7 \mathrm{a}$ & 48.6 \\
\hline $\mathrm{CP}\left(\mathrm{g} \mathrm{kg}^{-1}\right)$ & $103.7 \mathrm{~A}$ & 13.1 & $88.0 \mathrm{Ba}$ & 12.6 & $78.2 \mathrm{~b}$ & 11.7 \\
\hline $\operatorname{NDF}\left(\mathrm{g} \mathrm{kg}^{-1}\right)$ & $649.2 \mathrm{~A}$ & 23.8 & $656.2 \mathrm{Ab}$ & 26.6 & $693.4 \mathrm{a}$ & 30.4 \\
\hline $\mathrm{ADF}\left(\mathrm{g} \mathrm{kg}^{-1}\right)$ & $311.4 \mathrm{~A}$ & 15.8 & $301.0 \mathrm{Bb}$ & 15.8 & $370.0 \mathrm{a}$ & 35.0 \\
\hline Hemi $\left(\mathrm{g} \mathrm{kg}^{-1}\right)$ & $335.7 \mathrm{~B}$ & 14.3 & $355.2 \mathrm{Aa}$ & 16.9 & $323.3 \mathrm{~b}$ & 34.4 \\
\hline Lignin $\left(\mathrm{g} \mathrm{kg}^{-1}\right)$ & $21.4 \mathrm{~A}$ & 4.6 & $17.2 \mathrm{Bb}$ & 3.0 & $27.4 \mathrm{a}$ & 5.5 \\
\hline Cellulose $\left(\mathrm{g} \mathrm{kg}^{-1}\right)$ & $289.9 \mathrm{~A}$ & 15.8 & $281.6 \mathrm{Bb}$ & 12.8 & $343.3 \mathrm{a}$ & 32.7 \\
\hline IVDMD ( $\left.\mathrm{g} \mathrm{kg}^{-1}\right)$ & $789.0 \mathrm{~B}$ & 36.4 & $821.1 \mathrm{Aa}$ & 21.9 & $791.7 \mathrm{~b}$ & 35.1 \\
\hline \multirow[t]{2}{*}{ TDN $\left(\mathrm{g} \mathrm{kg}^{-1}\right)$} & $567.1 \mathrm{~A}$ & 9.9 & $564.2 \mathrm{Aa}$ & 11.1 & $548.7 \mathrm{~b}$ & 12.7 \\
\hline & \multicolumn{6}{|c|}{ Stem + sheath } \\
\hline $\mathrm{DM}\left(\mathrm{g} \mathrm{kg}^{-1}\right)$ & $263.4 \mathrm{~A}$ & 25.3 & $262.9 \mathrm{Aa}$ & 33.6 & $335.3 \mathrm{~b}$ & 61.2 \\
\hline $\mathrm{CP}\left(\mathrm{g} \mathrm{kg}^{-1}\right)$ & $45.2 \mathrm{~B}$ & 7.5 & $48.9 \mathrm{Aa}$ & 6.6 & $32.0 \mathrm{~b}$ & 6.3 \\
\hline $\operatorname{NDF}\left(\mathrm{g} \mathrm{kg}^{-1}\right)$ & $738.4 \mathrm{~A}$ & 23.1 & $723.9 \mathrm{Bb}$ & 24.8 & $802.8 \mathrm{a}$ & 25.9 \\
\hline $\operatorname{ADF}\left(\mathrm{g} \mathrm{kg}^{-1}\right)$ & $387.5 \mathrm{~A}$ & 21.8 & $365.8 \mathrm{Bb}$ & 21.8 & $490.5 \mathrm{a}$ & 41.6 \\
\hline Hemi $\left(\mathrm{g} \mathrm{kg}^{-1}\right)$ & $352.5 \mathrm{~A}$ & 22.6 & $358.1 \mathrm{Aa}$ & 20.4 & $312.2 \mathrm{~b}$ & 30.8 \\
\hline $\operatorname{Lignin}\left(\mathrm{g} \mathrm{kg}^{-1}\right)$ & $35.7 \mathrm{~A}$ & 6.6 & $28.0 \mathrm{Bb}$ & 5.2 & $62.3 \mathrm{a}$ & 11.4 \\
\hline Cellulose $\left(\mathrm{g} \mathrm{kg}^{-1}\right)$ & $352.3 \mathrm{~A}$ & 19.9 & $335.3 \mathrm{Ab}$ & 19.7 & $426.6 \mathrm{a}$ & 27.2 \\
\hline $\operatorname{IVDMD}\left(\mathrm{g} \mathrm{kg}^{-1}\right)$ & $698.5 \mathrm{~B}$ & 35.6 & $732.9 \mathrm{Aa}$ & 51.1 & $553.0 \mathrm{~b}$ & 63.6 \\
\hline $\operatorname{TDN}\left(\mathrm{g} \mathrm{kg}^{-1}\right)$ & $529.9 \mathrm{~B}$ & 9.6 & $536.0 \mathrm{Aa}$ & 10.3 & $503.0 \mathrm{~b}$ & 10.8 \\
\hline
\end{tabular}

DM: dry matter; CP: crude protein; NDF: neutral detergent fiber; ADF: acid detergent fiber ; Hemi: hemicellulose; DP: desvio

padrão. In soils developed from basalt, averages followed by different capital letters on the same line differ $(\mathrm{P}<0.05)$ according to the season of the year. In spring, averages followed by different lowercase letters on the same line differ $(\mathrm{P}<0.05)$ according on the type of soil.

The protein content of the leaf blade indicates good nutritional status, but the values in the stem + sheath were below the desired minimum (Table 2). Minson (1990) stated that for adequate microbial fermentation in the rumen, the $\mathrm{CP}$ content of the diet should be at least $7 \%$ in DM. Under the 
conditions of the present study, considering the canopy composition, only the basalt area (in both seasons) could provide protein contents bigger than $7 \%$. The lower proportion in the leaf blade:stem + sheath of sandstone soil-grown plants would provide a $5 \% \mathrm{CP}$ content in the pasture, which is below the recommended minimum. According to Euclides et al. (2001), the forage must have a protein concentration of around $12 \%$ in DM so that the nutritional requirements of beef cattle are supplied. When this does not happen, dietary supplements may be the most suitable option to provide the recommended dietary contents. Thus, in this study, $38 \%$ (basalt) to $55 \%$ (sandstone) of the protein needs of the animal are not supplied by Brachiaria grass and should be provided through dietary supplements.

The NDF content was lower in the leaf blades $\left(649.2-693.4 \mathrm{~g} \mathrm{~kg}^{-1}\right)$ than in the stem + sheath (723.9-802.8 $\left.\mathrm{g} \mathrm{kg}^{-1}\right)$. There was a difference in the NDF content as a function of the season. On the other hand, there was a difference $(P<0.05)$, especially for the composite fraction of the stem + sheath, between the NDF contents found in forage from soils developed from basalt (723.9 $\left.\mathrm{g} \mathrm{kg}^{-1}\right)$ and sandstone (802.8 $\mathrm{g} \mathrm{kg}^{-1}$ ) (Table 2). According to Van Soest (1994), NDF levels above 60\% may negatively affect animal consumption. However, it should be considered that the tropical forages hardly present values below the recommended levels when the management and cutting height indicated for the species are adopted (PEREIRA et al., 2011). The results obtained are in agreement with the indications of Pereira et al. (2011), Alencar et al. (2014), and Guerra et al. (2016), who verified that NDF values were always more than $60 \%$ in Brazilian pastures formed with different species of Brachiaria. High levels of NDF are a consequence of the proportional decrease in easily digestible molecules, mainly proteins, which play an important role in ruminant nutrition.

These variations in NDF content may be due to variations in the $\mathrm{ADF}$ content. The $\mathrm{ADF}$ levels were lower in the leaf blades (301-370 $\left.\mathrm{g} \mathrm{kg}^{-1}\right)$ than in the stem + sheath $\left(365.8-490.5 \mathrm{~g} \mathrm{~kg}^{-1}\right)$. The highest values found in the MS of the stem + sheath, in relation to the leaf blade, are justified because they contain the main tissues responsible for the structure and sustentation of the plant. In addition, the xylem tissue of plants develops simultaneously with their growth, so that water supply occurs in quantities sufficient to meet their requirements. Thus, cellulose and other carbohydrates accumulate in the tissues and trigger the lignification process, increasing the cell wall thickness and NDF contents (HOFFMAN et al., 2007). Lower levels of ADF in DM were found in the spring season in forage samples from soil developed from basalt $\left(301 \mathrm{~g} \mathrm{~kg}^{-1}\right.$ in the leaf blade, $365.8 \mathrm{~g} \mathrm{~kg}^{-1}$ in the stem + sheath; Table 2). The soil type had a significant effect on the ADF content of forage; it was notably higher in forage samples collected from soil developed from sandstone $\left(370 \mathrm{~g} \mathrm{~kg}^{-1}\right.$ in the leaf blade, $490.5 \mathrm{~g} \mathrm{~kg}^{-1}$ in the stem + sheath; Table 2) than in soil developed from basalt.

Hemicellulose contents, which correspond to the difference between NDF and ADF, presented a reduced variation, from $312.2-358.1 \mathrm{~g} \mathrm{~kg}^{-1}$, although differences as a function of the morphological structure, season and the soil type. The lignin and cellulose contents, fractions of the ADF, vary in a similar way to this, under the effect of soil type and season. The lignin contents increased by $1 \%-$ $3.5 \%$ and cellulose by $5.3 \%-8.4 \%$ in relation to the structure (leaf blade and stem + sheath) in the three study conditions, with the forage presenting better quality when grown in basalt soil during spring. The lower nutrient quality of the forage cultivar observed in sandstone soil is due to the interaction of soil-related factors with low fertility, high acidity (GAMA et al., 2009), and low water retention capacity, as well as the intrinsic factors of the plant, such as the stage of maturation and direct effects related to pasture management.

However, lower levels of ADF in the forage mass is expected, since this attribute works as an 
indication of the energy level and digestibility of the diet offered to the animals (OLIVEIRA et al., 2010). Therefore, the lower the ADF value, the higher the energy index and forage digestibility.

The highest values of digestibility (IVDMD) and TDN were verified during spring and in samples from soil developed from basalt (821.1 and 564.2 $\mathrm{g} \mathrm{kg}^{-1}$ in the leaf blade and 732.9 and $536 \mathrm{~g} \mathrm{~kg}^{-1}$ in the stem + sheath, respectively; Table 2). The digestibility (IVDMD) and TDN are directly influenced by the cell wall contents and non-fibrous carbohydrates. Cellulose, hemicellulose, and lignin are components of the cell wall, which differ in the degree of digestibility. While cellulose presents a low digestibility, hemicellulose is classified as a carbohydrate of moderate digestibility, and lignin is practically indigestible in the intestinal tract of the animals. The higher lignin and cellulose contents in pasture from the sandstone and the lower levels in those from basalt during spring explain, respectively, the lowest and highest digestibilities found.

In relation to the season, the IVDMD presented differences $(P<0.05)$ in the leaf blade and the stem + sheath, and TDN showed a difference in only the stem + sheath. The forage produced in the spring showed an IVDMD $4.6 \%$ higher than that produced in autumn. On the other hand, the material of soil origin influenced $(P<0.05)$ the IVDMD and TDN in both structures, with contents of 15.1 and $5 \%$, respectively, which was higher in soil developed from basalt when compared to that developed from sandstone. The gradual reduction in forage digestibility occurs due to the progressive thickening of the cell wall and its subsequent lignification (MINSON, 1990; VELÁSQUEZ et al., 2010), which occurs as the plant progresses to the maturation stage. Therefore, it is nutritionally advantageous to provide animals with a biologically younger fodder with higher levels of easily digestible fibers, such as hemicellulose.

\section{Soil nutrients}

The influence $(P<0.05)$ of the source material was observed in the composition of the two soils analyzed in spring for macro and micronutrients, except for P. The basalt soil showed the highest nutrient contents (Table 3), contributing to a higher CEC and sum of bases (SB) (Table 1). According to Lima et al., (2007) it is common to find a low CEC value in the surface horizons of sandy soils, which may vary according to the amount of organic matter and clay, as well as soil $\mathrm{pH}$ value (MIELNICZUK, 1982).

Table 3. Mean and standard deviation (SD) of macro and micronutrients in soils developed from basalt or sandstone.

\begin{tabular}{|c|c|c|c|c|}
\hline \multirow{2}{*}{ Nutrients } & \multicolumn{2}{|c|}{ Basalt } & \multicolumn{2}{|c|}{ Sandstone } \\
\hline & Mean & SD & Mean & SD \\
\hline $\mathrm{K}\left(\mathrm{cmol}_{\mathrm{c}} \mathrm{kg}^{-1}\right)$ & $0.8 \mathrm{a}$ & 0.3 & $0.1 \mathrm{~b}$ & 0.1 \\
\hline $\mathrm{P}\left(\mathrm{mg} \mathrm{kg}^{-1}\right)$ & $12.0 \mathrm{a}$ & 7.9 & $10.7 \mathrm{a}$ & 6.6 \\
\hline $\mathrm{Ca}\left(\mathrm{cmol}_{\mathrm{c}} \mathrm{kg}^{-1}\right)$ & $7.5 \mathrm{a}$ & 2.1 & $2.4 \mathrm{~b}$ & 1.5 \\
\hline $\mathrm{Mg}\left(\mathrm{cmol}_{\mathrm{c}} \mathrm{kg}^{-1}\right)$ & $2.3 \mathrm{a}$ & 0.6 & $0.9 \mathrm{~b}$ & 0.5 \\
\hline $\operatorname{Mn}\left(\mathrm{mg} \mathrm{kg}^{-1}\right)$ & $542.5 \mathrm{a}$ & 167.7 & $380.4 \mathrm{~b}$ & 144.3 \\
\hline $\mathrm{Zn}\left(\mathrm{mg} \mathrm{kg}^{-1}\right)$ & $52.0 \mathrm{a}$ & 22.9 & $7.7 \mathrm{~b}$ & 4.1 \\
\hline
\end{tabular}

SD: standard deviation. Means followed by different letters on the same line differ $(\mathrm{P}<0.05)$, according to soil type.

According to Paraná State Nucleus of the Brazilian Society of Soil Science (SBCS/NEPAR, 2017), soil nutrients may be considered high or very high, except for $\mathrm{K}$ and $\mathrm{Mg}$ in the soil developed from sandstone, which were considered low and medium, respectively. In spite of this classification, 
the soil was able to supply the nutrients required by the forage, presenting, for the most part, contents within the recommended levels for the growth and production of the pasture.

The lower levels of $\mathrm{K}$ in the soil developed from sandstone may explain the lower contents of this mineral in the leaf blade $\left(17.5 \mathrm{~g} \mathrm{~kg}^{-1}\right)$ and in the stem + sheath $\left(13.1 \mathrm{~g} \mathrm{~kg}^{-1}\right)$ (Table 4). However, it can be considered that the contents still remained higher than the minimum levels required (12 g $\mathrm{kg}^{-1}$ in the aerial part) according to Oliveira et al. (2007). The lowest levels found in the sandy soil are justified by the low CEC and consequent leaching (WERLE et al., 2008). The availability of $\mathrm{K}$ in the soil is related to soil CEC, and well-drained soils with lower CECs may suffer higher K leaching (RAIJ, 1991). Sandy soils usually present a lower retention capacity of this nutrient, as evidenced in this study. On the other hand, soils with a high CEC have lower $\mathrm{K}$ contents in the solution, reduced losses due to leaching, and a higher storage capacity of $\mathrm{K}$ in the soil; in addition, clayey soils usually have a higher K content (WERLE et al., 2008).

Although the $\mathrm{P}$ values were considered to be very high (SBCS/NEPAR, 2017), they remained at 10.7 and $12 \mathrm{mg} \mathrm{kg}^{-1}$ in the sandstone and basalt soil, respectively (Table 3), and were able to guarantee a good production of dry mass in the forage, since this nutrient favors the growth of the aerial part and tillers. The sandy soils present low P levels available to the pastures (NAIME, 1994), but in this study there was no difference in this mineral between the soil types (Table 3).

The analysis of the Ca: $\mathrm{Mg}$ ratio is important in the soil, since according to Moreira et al. (1999), they compete for the same adsorption sites in the soil and in the process of absorption by the roots. However, the ratio was adequate, being 3.3:1 and 2.7:1 in soils developed from basalt and sandstone, respectively. The exchangeable $\mathrm{Ca}$ and $\mathrm{Mg}$ contents present great relationships with the CEC and SB. According to Paraná State Nucleus of the Brazilian
Society of Soil Science (SBCS/NEPAR, 2017), the levels of Ca were very high $\left(7.5 \mathrm{cmol}_{\mathrm{c}} \mathrm{kg}^{-1}\right)$ and high (2.4 cmolc kg-1); and for $\mathrm{Mg}$, very high (2.3 $\mathrm{cmol}_{\mathrm{c}}$ $\left.\mathrm{kg}^{-1}\right)$ and medium $\left(0.9 \mathrm{cmol}_{\mathrm{c}} \mathrm{kg}^{-1}\right)$, in soil developed from basalt and sandstone, respectively. Thus, it can be affirmed that no deficiency was observed in the contents of $\mathrm{Ca}, \mathrm{K}$, and $\mathrm{P}$ in the analyzed soils, unlike Vendrame et al. (2010) who reported their deficiency in pastures in the Brazilian Cerrado region.

The so-called essential cations, such as $\mathrm{Ca}^{+}, \mathrm{Mg}^{+}$, and $\mathrm{K}^{+}$, determine the soil $\mathrm{CEC}$, and this, together with $\mathrm{SB}$, is indicative of soil fertility. Ronquim (2010) stated that when the CEC is constituted mostly by these cations, the soil is considered of good quality for the nutrition and development of the plants.

For micronutrients, Paraná State Nucleus of the Brazilian Society of Soil Science (SBCS/NEPAR, 2017) recommended avoiding contents above 200 mg kg-1 of manganese and above $30 \mathrm{mg} \mathrm{kg}^{-1}$ of zinc. High Mn contents are therefore observed in both soil types, and $\mathrm{Zn}$ in the developed soils of basalt (Table 3). Zinc is considered one of the most deficient micronutrients, especially in sandy soils (GONÇALVES JÚNIOR et al., 2010).

High nutrient content, generally found in soil, can result from the mineralization of plant residues and animal waste. According to Sarmento et al. (2008), animal waste contains minerals that are not metabolized by the animal and are released and collected by the soil. On the other hand, the availability of these micronutrients is related to the forms of the elements in the soil and the sorption capacity of the soil. In the soil, the available metals are in the form of cations $\left(\mathrm{Zn}^{2+}, \mathrm{Mn}^{2+}\right)$ moving by diffusion in favor of the concentration gradient, from medium to low concentrations (MALAVOLTA, 2006), or in the form of hydroxides, oxides or salts, which have poor solubility at $\mathrm{pH}$ values above 7 .

Bergstrom et al. (2000) reported that clayey soils with higher amounts of organic matter have higher binding energy and adsorption capacity 
when compared to sandy soils with low organic matter. The content and type of clay may influence the availability of zinc (ABREU et al., 2007), as its adsorption varies with iron, aluminum and manganese oxides (RESENDE et al., 2002), being higher in clay soils and deficient in sandy soils with low organic matter (COSTA FILHO; PRADO, 2008). According to Fischer et al. (2007), from

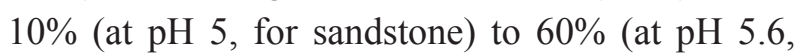
for basalt) of $\mathrm{Zn}^{2+}$ is adsorbed to hydrated $\mathrm{Fe}_{2} \mathrm{O}_{3}$, whereas less than $10 \%$ of $\mathrm{Mn}^{+2}$ is adsorbed at $\mathrm{pH}$ values below 6 .

\section{Nutrient contents of morphological structures}

Forage plants have high soil nutrient extraction potential when compared to those of other crops (GARCIA et al., 2015). The mineral matter content was higher in the leaf blades $\left(90-115.1 \mathrm{~g} \mathrm{~kg}^{-1}\right)$ than in the stem + sheath (63.9-103.4 $\left.\mathrm{g} \mathrm{kg}^{-1}\right)$ (Table 4). It was higher in the leaf blades in autumn, and in the stem + sheath in spring, both in soil developed from basalt.

The nitrogen content varied from 12.5-16.6 $\mathrm{g}$ $\mathrm{kg}^{-1}$ in the leaf blades and from $5.1-7.8 \mathrm{~g} \mathrm{~kg}^{-1}$ in the stem + sheath (Table 4). It is one of the nutrients most required by plants, and about $80 \%-85 \%$ of the content is found in the protein fraction (MENGEL; KIRKBY, 2001). In this way, its deficiency causes a reduction in the growth and development of the plant. Considering the forage area, the $\mathrm{N}$ content was below the minimum required for this cultivar, from 13-20 $\mathrm{g} \mathrm{kg}^{-1}$ (OLIVEIRA et al., 2007), under all study conditions. Therefore, this nutrient may have limited plant development, contributing to the low protein content found in the leaf blades and the stem + sheath (Table 2), mainly in sandstone soil. This fact can be explained by the lack of nitrogen fertilization, which usually occurs in pasture areas.

The nutrient observed in most of the forage, in both structures (leaf blade and stem + sheath), was K. Higher levels of this nutrient were found in forage grown in soil developed from basalt (24.9-
$26.1 \mathrm{~g} \mathrm{~kg}^{-1}$ and $18.6-19.3 \mathrm{~g} \mathrm{~kg}^{-1}$ in the leaf blade and stem + sheath, respectively), and did not differ between seasons (Table 4). The species Brachiaria brizantha presents a high potential for extracting this mineral, which acts on the formation of sugars, carbohydrates, starch, protein synthesis, and cell division of the roots and other plant structures (KHAN et al., 2015), as well as being essential for the regrowth and maintenance of pastures (CABRAL et al., 2012).

Higher levels of $\mathrm{K}$ were observed in forage produced in soil developed from basalt, in agreement with the results of Teixeira (2016), who worked with Mombaça grass in Quartzarenic Neosol and Argisol, and observed higher leaf contents of K. According to McDowell and Valle (2000), the reduction of potassium content in a plant can be observed as its maturity increases. Moreover, the potassium content in forage varies according to the availability of this nutrient in the soil, since it is a moving element in the soil and can be absorbed beyond the forage requirement (PRIMAVESI et al., 2006). The levels of $\mathrm{K}$ in the forage were $23,22.3$, and $15.2 \mathrm{~g} \mathrm{~kg}^{-1}$ for soil samples developed from basalt in autumn and spring, and soil developed from sandstone, respectively, and were within the reference value for forage, between 12 and $30 \mathrm{~g} \mathrm{~kg}^{-1}$ (OLIVEIRA et al., 2007) and for beef cattle requirements, from 6-7 $\mathrm{g} \mathrm{kg}^{-1} \mathrm{DM}$, with maximum limits of $30 \mathrm{~g} \mathrm{~kg}^{-1}$ (NRC, 1996). Thus, it is stated that this nutrient did not limit the development of the plant and provided levels appropriate to the requirement of the animals. According to Sarmento et al. (2008), K is rarely added to mineral mixtures supplied to the herd, and forage is its main source.

Regardless of the morphological structure analyzed, the highest $\mathrm{P}$ content was observed during the autumn, with 4.2 and $4.4 \mathrm{~g} \mathrm{~kg}^{-1}$ in the leaf blade and stem + sheath, respectively (Table 4). This can be explained by the maturation of the plant; according to Coates et al. (1990), the content of this mineral declines with the advancement of plant age. This nutrient plays a fundamental role in the 
production and establishment of plants, especially forage crops, which for implantation in the growing area require rapid root system growth (CABRAL et al., 2012), which influences the stocking rate and productivity of the herd (EUCLIDES et al., 2009).

Table 4. Mean and standard deviation (SD) of mineral matter (MM), macro and micronutrients, in the dry matter (DM), of the leaf blades and stem + sheath of Brachiaria brizantha cv. Marandu cultivated in soil developed from basalt or sandstone, according to the seasons.

\begin{tabular}{|c|c|c|c|c|c|c|}
\hline \multirow{2}{*}{ Nutrients } & \multicolumn{2}{|c|}{ Basalt Autunm } & \multicolumn{2}{|c|}{ Basalt Spring } & \multicolumn{2}{|c|}{ Sandstone Spring } \\
\hline & Mean & $\mathrm{SD}$ & Mean & $\mathrm{SD}$ & Mean & $\mathrm{SD}$ \\
\hline & \multicolumn{6}{|c|}{ Leaf blade } \\
\hline $\mathrm{MM}\left(\mathrm{g} \mathrm{kg}^{-1}\right)$ & $115.1 \mathrm{~A}$ & 9.1 & $109.1 \mathrm{Ba}$ & 11.6 & $90.0 \mathrm{~b}$ & 10.7 \\
\hline $\mathrm{N}\left(\mathrm{g} \mathrm{kg}^{-1}\right)$ & $16.6 \mathrm{~A}$ & 2.1 & $14.1 \mathrm{Ba}$ & 2.0 & $12.5 \mathrm{~b}$ & 1.9 \\
\hline $\mathrm{K}\left(\mathrm{g} \mathrm{kg}^{-1}\right)$ & $26.1 \mathrm{~A}$ & 3.6 & $24.9 \mathrm{Aa}$ & 4.2 & $17.5 \mathrm{~b}$ & 3.7 \\
\hline$P\left(\mathrm{~g} \mathrm{~kg}^{-1}\right)$ & $4.2 \mathrm{~A}$ & 0.6 & $2.9 \mathrm{Ba}$ & 0.7 & $3.1 \mathrm{a}$ & 1.0 \\
\hline $\mathrm{Ca}\left(\mathrm{g} \mathrm{kg}^{-1}\right)$ & $1.6 \mathrm{~B}$ & 0.5 & $4.1 \mathrm{Ab}$ & 0.6 & $5.6 \mathrm{a}$ & 1.2 \\
\hline $\operatorname{Mg}\left(\mathrm{g} \mathrm{kg}^{-1}\right)$ & $1.3 \mathrm{~B}$ & 0.4 & $2.3 \mathrm{Aa}$ & 0.5 & $2.4 \mathrm{a}$ & 0.5 \\
\hline $\operatorname{Mn}\left(\mathrm{mg} \mathrm{kg}^{-1}\right)$ & $175.4 \mathrm{~A}$ & 59.4 & $186.4 \mathrm{Aa}$ & 55.0 & $165.3 \mathrm{~b}$ & 49.7 \\
\hline \multirow[t]{2}{*}{$\mathrm{Zn}\left(\mathrm{mg} \mathrm{kg}^{-1}\right)$} & $17.3 \mathrm{~B}$ & 7.2 & $20.6 \mathrm{Ab}$ & 5.5 & $23.6 \mathrm{a}$ & 7.0 \\
\hline & \multicolumn{6}{|c|}{ Stem + sheath } \\
\hline $\mathrm{MM}\left(\mathrm{g} \mathrm{kg}^{-1}\right)$ & $95.4 \mathrm{~B}$ & 9.3 & $103.4 \mathrm{Aa}$ & 13.3 & $63.9 \mathrm{~b}$ & 10.4 \\
\hline $\mathrm{N}\left(\mathrm{g} \mathrm{kg}^{-1}\right)$ & $7.2 \mathrm{~B}$ & 1.2 & 7.8 Aa & 1.1 & $5.1 \mathrm{~b}$ & 1.0 \\
\hline $\mathrm{K}\left(\mathrm{g} \mathrm{kg}^{-1}\right)$ & $19.3 \mathrm{~A}$ & 3.7 & $18.6 \mathrm{Aa}$ & 3.8 & $13.1 \mathrm{~b}$ & 3.7 \\
\hline $\mathrm{P}\left(\mathrm{g} \mathrm{kg}^{-1}\right)$ & $4.4 \mathrm{~A}$ & 0.6 & $3.5 \mathrm{Ba}$ & 0.6 & $3.0 \mathrm{~b}$ & 0.7 \\
\hline $\mathrm{Ca}\left(\mathrm{g} \mathrm{kg}^{-1}\right)$ & $0.9 \mathrm{~B}$ & 0.4 & $2.2 \mathrm{Aa}$ & 0.4 & $2.3 \mathrm{a}$ & 0.7 \\
\hline $\operatorname{Mg}\left(\mathrm{g} \mathrm{kg}^{-1}\right)$ & $1.1 \mathrm{~B}$ & 0.3 & $1.5 \mathrm{Ab}$ & 0.4 & $1.6 \mathrm{a}$ & 0.3 \\
\hline $\operatorname{Mn}\left(\mathrm{mg} \mathrm{kg}^{-1}\right)$ & $213.3 \mathrm{~A}$ & 75.5 & $154.5 \mathrm{Bb}$ & 75.9 & $179.7 \mathrm{a}$ & 39.0 \\
\hline $\mathrm{Zn}\left(\mathrm{mg} \mathrm{kg}^{-1}\right)$ & $78.2 \mathrm{~A}$ & 24.8 & $58.1 \mathrm{Ba}$ & 21.9 & $63.7 \mathrm{a}$ & 14.0 \\
\hline
\end{tabular}

In soils developed from basalt, averages followed by different capital letters on the same line differ $(\mathrm{P}<0.05)$ according to the season of the year. In spring, averages followed by different lowercase letters on the same line differ $(\mathrm{P}<0.05)$ according on the type of soil.

In the aerial part, the contents of $\mathrm{P}$ were 3.2 and $4.3 \mathrm{~g} \mathrm{~kg}^{-1}$ in spring and autumn, respectively. Considering that the indicated values of $\mathrm{P}$ are $0.8-$ $3.0 \mathrm{~g} \mathrm{~kg}^{-1}$ (OLIVEIRA et al., 2007) in the aerial part of the forage of this cultivar, the contents found in this study were similar and superior to that recommended, respectively. The highest levels can be justified by the higher soil density, which can cause greater contact of the nutrient with the root, contributing to a greater absorption of phosphorus by the plant (CABRAL et al., 2012). The levels of P in the plant suggest that they would be able to meet the requirements of beef cattle for this element, in both seasons and soil types, because according to the NRC (2000), the phosphorus requirement ranges from 1.7-2.2 $\mathrm{g} \mathrm{kg}^{-1} \mathrm{DM}$ for beef cattle.

In spite of the lower exchangeable $\mathrm{Ca}$ and $\mathrm{Mg}$ contents in the sandstone soil, higher absolute values were observed in the forage, during the spring for the soil developed from sandstone (5.6 and $2.4 \mathrm{~g} \mathrm{~kg}^{-1}$ in the leaf blade and 2.3 and $1.6 \mathrm{~g} \mathrm{~kg}^{-1}$ in the stem + sheath for $\mathrm{Ca}$ and $\mathrm{Mg}$, respectively; Table 4). However, among the source materials, the $\mathrm{Mg}$ contents did not differ in the leaf blades and the 
Ca content did not differ $(P>0.05)$ in the stem + sheath (Table 4). In autumn, the $\mathrm{Ca}$ and $\mathrm{Mg}$ contents were below the minimum limits of 3 and $1.5 \mathrm{~g} \mathrm{~kg}^{-1}$, respectively, according to the limits recommended by Oliveira et al. (2007); however, in spring, the values were adequate. Lower nutrient values than expected may also be due to the low availability of minerals in the soil, reduced plant genetic capacity in accumulating the element, or lower than indicated requirement for its growth (PEREIRA et al., 2011).

The calcium requirements of animals vary according to species, animal production, age, and weight. However, the bioavailability of calcium to ruminants depends on adequate levels of phosphorus in the diet, and this nutrient is responsible for the activation of vitamin $\mathrm{D}$ and the calcitonin and parathyroid hormones (KHAN et al., 2006). In Brazil, in general, pastures present adequate levels of calcium to meet bovine needs (GAMA et al., 2009); however, in autumn, only $1.2 \mathrm{~g} \mathrm{~kg}^{-1}$ were found in DM, which is below the requirement described by the NRC (2000), which is 1.8 to $4.4 \mathrm{~g}$ $\mathrm{kg}^{-1}$ in DM for beef cattle.

The leaf blades of the forage showed magnesium contents of $1.3 \mathrm{~g} \mathrm{~kg}^{-1}$ in samples from basalt soil in autumn and contents of 2.3 and $2.4 \mathrm{~g} \mathrm{~kg}^{-1}$ in spring in samples from both soil types, basalt and sandstone, respectively (Table 4), guaranteeing levels of 1.2$2 \mathrm{~g} \mathrm{~kg}^{-1}$ in the DM according to the requirements of beef cattle (NRC, 1996). Magnesium has great importance in ruminant feeding; its deficiency can lead to a nutritional imbalance, known as tetany. In addition, in the plant, this nutrient plays a fundamental role in the photochemical and metabolic reactions, as it is a component of the chlorophyll molecule (CASTRO et al., 2001). It also acts in the activation of enzymes responsible for the production of carbohydrates, fats, and sugars (KHAN et al., 2015).

In relation to the micronutrients analyzed, the leaf blade fraction in spring presented higher levels of manganese in forage grown on basalt soil (186.4 mg kg-1, Table 4) and the stem + sheath had higher Mn (213.3 mg kg-1, Table 4) in autumn. Regarding the forage aerial part, manganese levels were $192.6 \mathrm{mg} \mathrm{kg}^{-1}$ in autumn (basalt), and 173.1 $\mathrm{mg} \mathrm{kg}{ }^{-1}$ and $172.9 \mathrm{mg} \mathrm{kg}^{-1}$ in the spring season in basalt and sandstone soil, respectively. The contents of this nutrient are in accordance with the values recommended by Oliveira et al. (2007) from 40 to $250 \mathrm{mg} \mathrm{kg}^{-1}$ for the aerial part of the Marandu grass, such that the pasture is able to meet the nutritional needs of beef cattle (NRC, 2000), of $20 \mathrm{mg} \mathrm{kg}^{-1}$, and is below the toxic level of $1,000 \mathrm{mg} \mathrm{kg}^{-1}$.

The highest zinc contents were observed in the stem + sheath fraction of forage grown in basalt soil in autumn $\left(78.2 \mathrm{mg} \mathrm{kg}^{-1}\right)$, and showed higher values in the leaf blade $\left(23.6 \mathrm{mg} \mathrm{kg}^{-1}\right)$ of forage grown in sandstone soil. Considering the aerial part (leafblade and stem + sheath), the forage presented levels of 45 , 36.2 , and $44.7 \mathrm{mg} \mathrm{kg}^{-1}$ in autumn (basalt) and spring (basalt, sandstone), respectively, being within the appropriate range of requirement for the cultivar, which is from 20 to $50 \mathrm{mg} \mathrm{kg}^{-1}$ (OLIVEIRA et al., 2007). The minimum recommended zinc level for beef cattle is $30 \mathrm{mg} \mathrm{kg}^{-1}$, and it is recommended not to exceed $500 \mathrm{mg} \mathrm{kg}^{-1}$ (NRC, 2000).

However, the sandstone soil presented a $\mathrm{Zn}$ content six to seven times than that in basalt soil (Table 3). The forage cultivated showed, on average, results close to the one from basalt soil, which is justified by the soil $\mathrm{pH}$. The higher $\mathrm{pH}$ (Table 1) and probably higher iron oxide content in the basalt soil may provide a higher sorption of $\mathrm{Zn}$ (FISCHER et al., 2007) than that in the sandstone soil, and, therefore, sufficient bioavailability occurs for the plants despite the low $\mathrm{Zn}$ contents available in the sandstone soil (Table 3). In plants, zinc acts in the enzymatic processes; metabolism of carbohydrates, proteins, phosphates; and formation of auxins, RNA, and ribosomes (DECHEN et al., 1991), directly influencing their growth. Its availability is associated with the soil physicochemical characteristics, liming practices, and phosphate fertilization. 
It is important that pasture areas adopt adequate management practices that aim to maintain the canopy with the maximum number of young leaves, which usually have a better chemical composition. However, younger plants have higher nutritional requirements due to their higher metabolic activity (REIS et al., 2013), and this demand must be supplied by the soil.

\section{Conclusion}

In the spring season, forage cultivated in basalt soil ensures a better nutritional quality and digestibility.

The macro- and micronutrient contents in the basalt soil are superior to those in sandstone soil, except for the levels of $P$.

The Marandu cultivar meets the minimum requirements of $\mathrm{K}, \mathrm{P}, \mathrm{Mn}$, and $\mathrm{Zn}$ for beef cattle, except for $\mathrm{Ca}$ and $\mathrm{Mg}$ in autumn, and $\mathrm{N}$ in all conditions studied.

It is recommended to perform nitrogen fertilization and liming in the pastures, as well supplements the diet of animals with minerals, in order to complement the nutritional requirements and provide ideal conditions that allow the good performance of the herd.

\section{References}

ABREU, C. A.; LOPES, A. L.; SANTOS, G. Micronutrientes. In: NOVAIS, R. F.; ALVAREZ, V. V. H.; BARROS, N. F.; FONTES, R. L. F.; CANTARUTTI, R. B.; NEVES, J. C. L. Fertilidade do solo. Viçosa, MG: Sociedade Brasileira de Ciência do Solo, 2007. p. 645736.

ALENCAR, C. A. B.; MARTINS, C. E.; OLIVEIRA, R. A.; CÓSER, A. C.; CUNHA, F. F. Bromatologia e digestibilidade de gramineas manejadas por corte submetidas à adubações nitrogenadas e estações anuais. Bioscience Journal, Uberlândia, v. 30, n. 1, p. 8-15, 2014.

ASSOCIATION OF OFFICIAL AGRICULTURAL CHEMIST INTERNATIONAL - AOAC. Official methods of analysis of AOAC International. 17 $7^{\text {th }} \mathrm{ed}$. Gaithersburg: Association of Analytical Communities, 2000. 2200 p.
BARBOSA, F. A.; GRAÇA, D. S.; MAFFEI, W. E.; SILVA JÚNIOR, F. V.; SOUZA, G. M. Desempenho e consumo de matéria seca de bovinos sob suplementação proteico-energética, durante a época de transição águaseca. Arquivo Brasileiro de Medicina Veterinaria e Zootecnia, Belo Horizonte, v. 59, n. 1, p. 160-167, 2007.

BERGSTROM, D. W.; MONREAL, C. M.; TOMLIN, A. D.; MILLER, J. J. Interpretation of soil enzyme activities in a comparison of tillage practices along a topographic and textural gradient. Canadian Journal of Soil Science, Baltimore, v. 80, n. 3, p. 71-79, 2000.

CABRAL, C. E. A.; BONFIM-SILVA, E. M.; BONELLI, E. A.; SILVA, T. J. A.; CABRAL, C. H. A.; SCARAMUZZA, W. L. M. P. Compactação do solo e acronutrientes primários na Brachiaria brizantha $\mathrm{cv}$. Piatã e Panicum maximum cv. Mombaça. Revista Brasileira de Engenharia Agrícola e Ambiental, Campina Grande, v. 16, n. 4, p. 362-367, 2012.

CAPPELLE, E. R.; VALADARES FILHO, S. C.; SILVA, J. F. C.; CECON, P. R. Estimativas do valor energético a partir de características químicas e bromatológicas dos alimentos. Revista Brasileira de Zootecnia, Viçosa, MG, v. 30, n. 6, p. 1837-1856, 2001.

CASTRO, C. R. T.; GARCIA, R.; CARVALHO, M. M.; FREITAS, V. P. F. Efeitos do sombreamento na composição mineral de gramíneas forrageiras tropicais. Revista Brasileira de Zootecnia, Viçosa, MG, v. 30, n. 6, p. 1959-1968, 2001. Suplemento.

COATES, D. B.; KERRIDGE, P. C.; MILlER, C. P.; WINTER, W. H. Phosphorus and beef production in northern Australia. The effect of phosphorus on the composition, yield and quality of legume-based pasture and their relation to animal production. Tropical Grasslands, Peak Crossing, v. 24, n. 3, p. 209-220, 1990.

COSTA FILHO, R. T.; PRADO, R. M. Zinco na nutrição e na produção de colmos da terceira soqueira de canade-açúcar cultivada em um latossolo vermelho amarelo. Tecnologia/Pesquisa-STAB, Piracicaba, v. 26, n. 3, p. 6-9, 2008 .

COSTA, K. A. P.; OLIVEIRA, I. P.; SEVERIANO, E. C.; SAMPAIO, F. M. T.; CORRIJO, M. S.; RODRIGUES, C. R. Extração de nutrientes pela fitomassa de cultivares de Brachiaria brizantha sob doses de nitrogênio. Ciência Animal Brasileira, Goiânia, v. 11, n. 2, p. 307-314, 2010.

DECHEN, A. R.; HAAG, H. P.; CARMELLO, Q. A. C. Funções dos micronutrientes nas plantas. In: FERREIRA, M. E.; CRUZ, M. C. P. Micronutrientes na agricultura. Piracicaba: Instituto de Potassa e Fosfato, 1991. p. 65-78.

DETMANN, E.; SOUZA, M. A.; VALADARES FILHO, S. C.; QUEIROZ, A. C.; BERCHIELLI, T. T.; SALIBA, 
E. O. S.; CABRAL, L. S.; PINA, D. S.; LADEIRA M. M.; AZEVEDO, J. A. G. Métodos para Análise de Alimentos. Visconde do Rio Branco: UFV, 2012. 214 p.

EUCLIDES, V. P. B.; EUCLIDES FILHO, K.; COSTA, F. P. Desempenhos de novilhos F1 s Angus-Nelore em pastagem de Brachiaria decumbens submetidos a diferentes regimes alimentares. Revista Brasileira de Zootecnia, Viçosa, MG, v. 30, n. 2, p. 470-481, 2001.

EUCLIDES, V. P. B.; MACEDO, M. C. M.; VALLE, C. B.; DIFANTE, G. S.; BARBOSA, R. A.; CACERE, E. R. Valor nutritivo da forragem e produção animal em pastagens de Brachiaria brizantha. Pesquisa Agropecuária Brasileira, Brasília, v. 44, n. 1, p. 98-106, 2009.

EUCLIDES, V. P. B.; VALLE, C. B.; MACEDO, M. C. M.; ALMEIDA, R. G.; MONTAGNER, D. B.; BARBOSA, R. A. Brazilian scientific progress in pasture research during the first decade of XXI century. Revista Brasileira de Zootecnia, Viçosa, MG, v. 39, p. 151-168, 2010. Supplement Special.

FISCHER, L.; BRUMMER, G. W.; BARROW, N. J. Observations and modelling of the reactions of 10 metals with goethite: adsorption and diffusion processes. European Journal of Soil Science, Bedfordshire, v. 58, n. 6, p. 1304-1315, 2007.

FONSECA, F. P.; CZUY, D. C. Formação Arenito Caiuá: uso, ocupação do solo e problemas ambientais na região noroeste do Paraná. In: SIMPÓSIO NACIONAL DE GEOGRAFIA AGRÁRIA, SIMPÓSIO INTERNACIONAL DE GEOGRAFICA AGRÁRIA JORNADA ARIOVALDO UMBELINO DE OLIVEIRA, 2., 3., 2005, Presidente Prudente. Anais... Presidente Prudente: UNESP - Universidade Estadual Paulista, 2005. p. 1-7.

GAMA, T. C. M.; ZAGO, V. C. P.; NICODEMO, M. L. F.; LAURA, V. A.; VOLPE, E.; MORAIS, M. G. Composição bromatológica, digestibilidade in vitro e produção de biomassa de leguminosas forrageiras lenhosas cultivadas em solo arenoso. Revista Brasileira de Saúde e Produção Animal, Salvador, v. 10, n. 3, p. 560-572, 2009.

GARCIA, G. O.; RIGGO, M. M.; CECÍLIO, R. A.; REIS, E. F.; BERTOSSI, A. P. A. Massa seca e extração de nutrientes por duas forrageiras fertirrigadas com esgoto doméstico tratado. Bioscience Journal, Uberlândia, v. 31, n. 1, p. 215-226, 2015.

GONÇALVES JÚNIOR, A. C.; NACKE, H.; MARENGONI, N. G.; CARVALHO, E. A.; COELHO, G. F. Produtividade e componentes de produção da soja adubada com diferentes doses de fósforo, potássio e zinco. Ciência e Agrotecnologia, Lavras, v. 34, n. 3, p. 660-666, 2010.

GUERRA, G. L.; MIZUBUTI, I. Y.; RIBEIRO, E. L. A.; PRADO-CALIXTO, O. P.; SILVA, L. D. F.; PEREIRA, E. S.; MASSARO JÚNIOR, F. L.; GUERRA, A. L.; FERNANDES JÚNIOR, F.; HENZ, E.L. Supplementation of beef cattle grazing Brachiariabrizantha during the dry and rainy seasons: performance and carcass ultrasound prediction. Semina: Ciências Agrárias, Londrina, v. 37, n. 5, p. 3277-3292, 2016.

HOFFMAN, P. C.; LUNDBERG, K. M.; BAUMAN, L. M.; SHAVER, R. D.; CONTRERAS-GOVEA, F. E. El efecto de la madurez en la digestibilidad del FDN (fibra detergente neutro). Focus on Forage, Madison, v. 5, n. 15, p. 1-2, 2007.

KHAN, Z. I.; AHMAD, K.; ASHRAF, I.; GONDAL, S.; SHER, M.; HAYAT, Z.; LAUDADIO, V.; TUFARELLI, $\mathrm{V}$. Bioconcentration of some macrominerals in soil, forage and buffalo hair continuum: a case study on pasture irrigated with sewage water. Saudi Journal of Biological Sciences, Riyadh, v. 22, n. 3, p. 249-255, 2015.

KHAN, Z. I.; ASHRAF, M.; VALEEM, E. E. Forage mineral status evaluation: the influence of pastures. Pakistan Journal of Botany, Karachi, v. 38, n. 4, p. 10431054, 2006.

LIMA, J. J.; MATA, J. D. V.; PINHEIRO NETO, R.; SCAPIM, C. A. Influência da adubação orgânica nas propriedades químicas de um Latossolo Vermelho distrófico e na produção de matéria seca de Brachiaria brizantha cv. Marandu. Acta Scientiarum. Agronomy, Maringá, v. 29, p. 715-719, 2007. Suplemento.

MAGALHÃES, J. A.; CARNEIRO, M. S. S.; ANDRADE, A. C.; PEREIRA, E. S.; RODRIGUES, B. H. N.; COSTA, N. L.; FOGAÇA, F. H. S.; CASTRO, K. N. C.; TOWNSEND, C. R. Composição bromatologica do capim-Marandu sob efeito de irrigação e adubação nitrogenada. Semina: Ciências Agrárias, Londrina, v. 36, n. 2, p. 933-942, 2015.

MALAVOLTA, E. Manual de nutrição de plantas. São Paulo: Agronômica Ceres, 2006. 638 p.

MANTOVANI, J. R.; CARRERA, M.; MOREIRA, J. L. A.; MARQUES, D. J.; SILVA, A. B. Fertility properties and leafy vegetable production in soils fertilized with cattle manure. Revista Caatinga, Mossoró, v. 30, n. 4, p. 825-836, 2017.

MCDOWELL, L. R. Minerals in animals and livestock nutrition. San Diego: Academic Press, 1992. 524 p.

MCDOWELL, L. R.; VALLE, G. Major minerals in forages. In: GIVENS, D. I.; OWEN, E.; OXFORD, R. 
F. E.; OMED, H. M. Forage evaluation in ruminant nutrition. Wallingford: CAB International, 2000, p. 373398.

MENGEL, K.; KIRKBY, E. A. Principles of plant nutrition. Dordrechth: Kluwer Academic Publishers, 2001. 849 p.

MESQUITA, E. E.; PINTO, J. C.; FURTINI NETO, A. E.; SANTOS, I. P. A.; TAVARES, V. B. Teores críticos de fósforo em três solos para o estabelecimento de capimmombaça, capim, marandu e capim-andropogon em vasos. Revista Brasileira de Zootecnia, Viçosa, MG, v. 33, n. 2, p. 290-301, 2004.

MIELNICZUK, J. Avaliação da resposta das culturas ao potássio em ensaios de longa duração: experiências brasileiras. In: YAMADA, T.; MUZZILLI, O.; USHERWOOD, N. R. (Ed.). Potássio na agricultura brasileira. Piracicaba: Instituto da Potassa e Fosfato, 1982. p. 289-303.

MINEROPAR. Atlas comentado da geologia e dos recursos minerais do estado do Paraná. Curitiba: Mineropar, 2001. 116 p.

MINSON, D. J. Forage in ruminant nutrition. San Diego: Academic Press, 1990. 483 p.

MOREIRA, A.; CARVAlHO, J. G.; EVANGELISTA, A. R. Influência da relação cálcio:magnésio do corretivo na nodulação, produção e composição mineral da alfafa. Pesquisa Agropecuária Brasileira, Brasília, v. 34, n. 2, p. 249-255, 1999.

NAIME, J. U. Solos da área mineira do polígono das secas. Revista Informe Agropecuário, Belo Horizonte, v. 17, n. 181, p. 10-15, 1994.

NATIONAL RESEARCH COUNCIL - NRC. Nutrient requirements of beef cattle. $7^{\text {th }}$ ed. Washington: National Academy Press, 1996. 244 p.

Nutrient requirements of beef cattle. $7^{\text {th }}$ ed. Washington: National Academy Press, 2000. 232 p.

NEELY, C.; BUNNING, S.; WILKES, A. Review of evidence on drylands pastoral systems and climate change implications and opportunities for mitigation and adaptation. Roma: FAO, Food and Agriculture Organization of the United Nations, 2009. 38 p.

OLIVEIRA, D. A.; BONFIM-SILVA, E. M.; SILVEIRA, C. P.; MONTEIRO, F. A. Valor nutritivo do capimbraquiária no primeiro ano de recuperação com aplicações de nitrogênio e enxofre. Revista Brasileira de Zootecnia, Viçosa, MG, v. 39, n. 4, p. 716-726, 2010.

OLIVEIRA, P. P. A.; MARCHESIN, W.; LUZ, P. H. C.; HERLING, V. R. Guia de identificação de deficiências nutricionais em Brachiaria brizantha cv. Marandu. São Carlos: EMBRAPA, 2007. 38 p. (Comunicado técnico, 76).

PACIUllo, D. S. C.; CARVAlho, C. A. B.; AROEIRA, L. J. M.; MORENZ, M. J. F.; LOPES, F. C. F.; ROSSIELLO, R. O. P. Morfofisiologia e valor nutritivo do capim-braquiária sob sombreamento natural e a sol pleno. Pesquisa Agropecuária Brasileira, Brasília, v. 42, n. 10, p. 573-579, 2007.

SCBS/NEPAR - SOCIEDADE BRASILEIRA DE CIENCIA DE SOLO. NUCLEO ESTADUAL PARANÁ. Manual de adubação e calagem para o estado do Paraná. Curitiba: SBCS/NEPAR, 2017. 482 p.

PAVAN, M. A.; BLOCH, M. de F.; ZEMPULSKI, H. da C.; MIYAZAWA, M.; ZOCOLER, D. C. Manual de análise química de solo e controle de qualidade. Londrina: IAPAR, 1992. 40 p. (IAPAR. Circular técnica, 76).

PEDREIRA, C. G. S.; BRAGA, G. J.; PORTELA, J. N. Herbage accumulation, plant-part composition and nutritive value on grazed signal grass (Brachiaria decumbens) pastures in response to stubble height and rest period based on canopy light interception. Crop and Pasture Science, Melbourne, v. 68, n. 1, p. 62-73, 2017.

PEREIRA, R. C.; RIBEIRO, K. G.; PEREIRA, O. G.; VILlELA, S. D. J.; SILVA, J. L. Produtividade, composição químico-bromatologica e extração de minerais das cultivares Marandu e Xaraés nas estações do ano. Veterinária e Zootecnia, Botucatu, v. 18, n. 4, p. 570-582, dez. 2011.

PRIMAVESI, A. C.; PRIMAVESI, O.; CORRÊA, L. A.; SILVA, G. A.; CANTARELLA, H. Nutrientes na fitomassa de capim-marandu em função de fontes e doses de nitrogênio. Ciência e Agrotecnologia, Lavras, v. 30, n. 3, p. 562-568, 2006.

RAIJ, B. van. Fertilidade do solo e adubação. Piracicaba: Ceres, 1991. 343 p.

REIS, G. L.; LANA, A. M. Q.; EMERCENCIANO NETO, J. V.; LEMOS FILHO, J. P.; BORGES, I.; LONGO, R. M. Produção e composição bromatológica do capimmarandu, sob diferentes percentuais de sombreamento e doses de nitrogênio. Bioscience Journal, Uberlândia, v. 29, p. 1606-1615, 2013. Supplement 1.

RESENDE, M.; CURI, N.; REZENDE, S. B. de; CORRÊA, G. F. Pedologia: bases para a distinção de ambientes. 4. ed. Viçosa, MG: NEPUT, 2002. 338 p.

RONQUIM, C. C. Conceitos de fertilidade do solo e maneko adequado para as regiões tropicais. Campinas: EMBRAPA Monitoramento por Satélite, 2010. 26 p. 
SANCHEZ, P. A.; LOGAN, I. J. Myrths and science about the chemistry and fertility of soil in the tropies. In: LAL, R.; SANCHEZ, P. A. (Ed.). Myrths and science of soil of the tropics. Madison: Soil Science Society of América, 1992. p. 18-33. (SSSA Special. Publi, n. 29).

SANTOS, D. C.; GUIMARÃES JÚNIOR, R.; VILELA, L.; PULROLNIK, K.; BUFON, V. B.; FRANÇA, A. F. S. Forage dry mass accumulation and structural characteristics of Piatã grass in silvopastoral systems in the Brazilian savannah. Agriculture, Ecosystems and Environment, Amsterdam, v. 233, p. 16-24, 2016.

SANTOS, H. G.; JACOMINE, P. K. T.; ANJOS, L. H. C.; OLIVEIRA, V. A.; LUMBRERAS, J. F.; COELHO, M. R.; ALMEIDA, J. A.; CUNHA, T. J. F.; OLIVEIRA, J. B. Sistema brasileiro de classificação de solos. 3. ed. rev. e ampl. Brasília: EMBRAPA, 2013. 353 p.

SARMENTO, P.; RODRIGUES, L. R. A.; CRUZ, M. C. P.; LUGÃO, S. M. B.; CAMPOS, F. P.; CENTURION, J. F.; FERREIRA, M. E. Atributos químicos e físicos de um argissolo cultivado com Panicum maximum jacq. cv. Ipr-86 milênio, sob lotação rotacionada e adubado com nitrogênio. Revista Brasileira de Ciência do Solo, Campinas, v. 32, p. 183-193, 2008.

SILVA, F. C. Manual de análises químicas de solos, plantas e fertilizantes. 2. ed. rev. ampl. Brasília: EMBRAPA Informação Tecnológica, 2009. 627 p.

SILVA, L. F.; MIELNICZUK, J. Sistemas de cultivo e características do solo afetando a estabilidade de agregados. Revista Brasileira de Ciência do Solo, Campinas, v. 22, n. 2, p. 311-317, 1998.
TEIXEIRA, N. M. Adubação foliar de zinco quelatizado e seus efeitos na produção de capim-mombaça. 2016. Dissertação (Mestrado em Ciência e Tecnologia Animal) - Faculdade de Ciências Agrárias e Tecnológicas de Dracena, Universidade Estadual Paulista, Dracena.

TILLEY, J. M. A.; TERRY, R. A. A two-stage technique for the in vitro digestion of forage crop. Journal British Grassland Society, Oxford, v. 18, n. 2, p. 104-111, 1963.

VAN SOEST, P. J. Nutritional ecology of the ruminant. $2^{\text {th }}$ ed. Ithaca: Cornell University, 1994. 476 p.

VAN SOEST, P. J.; ROBERTSON, J. B.; LEWIS, B. A. Methods of the determination of FDN, FDA and CNE. Journal of Dairy Science, Champaign, v. 74, n. 10, p. 3583-3597, 1991.

VELÁSQUEZ, P. A. T.; BERCHIELLI, T. T.; REIS, R. A.; RIVERA, A. R.; DIAN, P. H. M.; TEIXEIRA, I. A. M. A. Composição química, fracionamento de carboidratos e proteínas e digestibilidade in vitro de forrageiras tropicais em diferentes idades de corte. Revista Brasileira de Zootecnia, Viçosa, MG, v. 39, n. 6, p. 1206-1213, 2010.

VENDRAME, P. R. S.; BRITO, O. R.; GUIMARÃES, M. F.; MARTINS, E. S.; BECQUER, T. Fertility and acidity status of latossolos (oxisols) under pasture in the Brazilian Cerrado. Annals of the Brazilian Academy of Sciences, Rio de Janeiro, v. 82, n. 4, p. 1085-1094, 2010.

WERLE, R.; GARCIA, R. A.; ROSOLEM, C. A. Lixiviação de potássio em função da textura e da disponibilidade do nutriente no solo. Revista Brasileira de Ciência do Solo, Viçosa, MG, v. 32, n. 6, p. $2297-$ 2305, 2008. 